\title{
THE IMPACT OF MEDIATED INSTRUCTION OF TEXT (MIT) STRATEGY IN TEACHING READING SKILL TO THE STUDENTS OF SMP NEGERI 13 BANDA ACEH
}

\author{
Sariakin $^{(1)}$, Maulizan ZA ${ }^{(2)}$ \\ 1,2 Bina Bangsa Getsempena University \\ Email: ${ }^{1}$ Sariakin70@gmail.com, ${ }^{2}$ maulizanza@gmail.com
}

\begin{abstract}
The aim of the research to find out if the use of Mediated Instruction of Text (MIT) strategy in reading skill can improve the eight grade students' ability of SMP Negeri 13 Banda Aceh in mastering reading skill. This research is conducted by using pre-experiment with one class; pretest and post-test design. The population of this research is the eight grade students of SMP Negeri 13 Banda Aceh. The total population of this study is 121 students who are composed of five classes; VIII1, VIII2, VIII3, and VIII4. Every class consists of about 30 students. Since the population was rather big thus writer takes sample for this study. The sample of this research was class VIII1 at second grade of SMP Negeri 13 Banda Aceh. The class consisted of 30 students. The researcher used purposive sampling technique in choosing sample. The researcher chooses the students of class VIII1 because the students' ability of the class is better than the other classes. The data are taken through test. The data gotten are analyzed by using gain score (GS). The result of this research shows that Gain Score (GS) score is 0.24. It means there is a difference between the students' ability in mastering reading skill before and after they are taught by using MIT strategy and the difference is 0.24 points or $24 \%$. Therefore, the students' ability in mastering reading skill increases 0.24 points or $24 \%$ after they are taught by using MIT strategy. Based on the result of the study, the English teachers of SMP Negeri 13 Banda Aceh should use MIT strategy in teaching reading skill because it can increase the students' ability in mastering reading skill.
\end{abstract}

Key Words: Impact, Mediated Instruction of Text Strategy, Reading Skill

\section{Introduction}

Reading is one of the most important aspects in teaching English. It is because reading can help students in comprehending English reading text, and can get information from what they have read and comprehend most of the books written in English (Nunan, 2003). Next, besides the aim of teaching reading is to develop good reading strategies, such as skimming, scanning, looking for information, etc. (Nunan, 2003). To have a good mastery in learning English, especially reading, the students are not only expected to read appropriately but also to be able to understand what they have read and can answer the questions given. In understanding main idea or important information from the text they have to master reading as a language skill, exactly reading comprehension.

Reading is reciting the symbolism of written language. Reading is not only spelling the word but also understanding and comprehending the content of writing, analyzing the information, taking the conclusion, and determining the main idea in the text. The good reading maybe the ability to scan rapidly and to process large quantities of material quickly (Mikulecky \& Jeffries, 2004). It means that a good reader is the one who is able to comprehend what he/she 
reads. Therefore, the student must understand the contents of the text.

Furthermore, Maysa' (2011) says that reading required student to be able to understand reading text or passage, commonly it has some purposes such as to get information through reading text or passage, reading make students can obtain a lot of information". It means by understanding reading text or passage, students are expected to get information and improve students' knowledge. So, through teaching reading, the students not only able to comprehend, but also can develop their reading strategies, such as skimming, scanning and looking for information.

It is generally understood that for the certain purposes reading makes us aware of what has happened or what is happening or even what will happen in the future. Reading materials generally read by people include newspapers, magazines, or reports, textbooks, novels of all kinds, short stories, journals, periodicals, poems, etc. Reading process begins with a series of expectations about the subjects to read which are confirmed, modified while reading takes place.

Based on the above question, reading is a common strategy how to teach English at junior high school students. Thus, teaching reading is important for any high school, since it is one of the four language skills. There are factors that help one understand what he reads.

However, many students can not comprehend reading now days because they do not have interest to learn comprehend reading. This condition also happens to the eight grade students of SMP Negeri 13 Banda Aceh. When the writer conducted a preliminary study on February 21, 2018 till February 25, 2018, the writer found that the students' ability in mastering reading comprehension was not satisfying because their average score in reading skill was only 56. Meanwhile the standard score of the lesson was 75 at the school. There were some factors that caused it and one of them was strategy used by teacher could not motivate the students in learning reading comprehension. Thus they were not interested in learning reading comprehension. Besides reading material used by teachers was unattractive. These factors caused this issue. Thus, Consequently, their ability in mastering reading skill was low. To solve these problems, several reading approaches have been applied including by using MIT (Mediated Instruction of Text) Strategy. It is believed that the use of strategy in teaching reading skill can increase students' interest thus it will make them easier to read and understand the point of reading materials.

By considering the explanation above, the writer is interested to choose one of the appropriate strategy in teaching reading by using MIT (Mediated Instruction of Text) Strategy. According to Neal and Langer (2002), mediated instruction of texts strategy refers to the teacher's role in making decisions during comprehension lessons which are intended to guide the students through an assignment with respect to the reading tasks. In addition, Neal and Langer (2002:) stated that instructional mediation may involve matching students' background to the content and organization of the text, guiding them to understand the texts' details, and provide opportunities to use the new information in a variety of ways.

Furthermore, one study by Mayasari (2011) results that the use of MIT (Mediated Instruction of Text) Strategy for reading comprehension is effective because the students' readiness, understanding and retention are integrated with the basic needs 
of learning like questioning, brain storming, creating complex thoughts, surveying ideas, building word meaning, responding to purpose questions and summarizing

Muhadjir (2012) states that teaching reading skill through (Mediated Instruction of Text) strategy can motivate the students to learn reading comprehension, The students can create complex thoughts, survey ideas, build word meaning, respond to purpose questions and summarizing. Thus this strategy is effective to improve students' achievement in mastering reading skill.

Next, the Mediated Instruction of Text (MIT) for content reading mediated instruction refers to the teacher's role in making decisions during comprehension lessons which are intended to guide the students through an assignment with respect to the reading tasks. Instructional mediation may involve matching students' background to the content and organization of the text, guiding them to understand the texts' details, and provide opportunities to use the new information in a variety of ways (Neal \& Langer, 2002).

These forms of mediations could be used in combinations before, during and after reading a text. The mediated instruction "philosophy assumes that instructors are responsible for "promoting interaction between the students and the textbook information" and for enabling the student's comprehension processes that define successful reading of expository material" (Neal \& Langer, 2001). In the content areas of reading instruction mediation requires two conditions. First, flexibility for planning is necessary because the instruction occurs in diverse subject matter fields. A second condition is clear view of how teachers help students learn from text (Neal \& Langer, 2002).

The (MIT) strategy is developed by Neal and Langer (2002) that provide teachers with a generalized paradigm. The followings are its major components:
1. Instructional goals for each reading phase.

2. Basic comprehension processes that ensure each goal is met.

3. Instructional strategies that promote reading comprehension.

4. Instructor responsibilities for each reading phase.

Next, the paradigm of MIT strategy can be drawn as follows:

Table 1.1 The MIT Paradigm

\begin{tabular}{|c|c|c|c|c|}
\hline $\begin{array}{c}\text { Reading } \\
\text { phase }\end{array}$ & $\begin{array}{l}\text { Rea } \\
\text { ding } \\
\text { goal }\end{array}$ & $\begin{array}{c}\text { Comp } \\
\text { rehens } \\
\text { ion } \\
\text { Proces } \\
\text { s/ } \\
\text { Stude } \\
\text { nt's } \\
\text { Role }\end{array}$ & $\begin{array}{c}\text { Learning } \\
\text { Strategies } \\
\text { Guiding the } \\
\text { Students' } \\
\text { Answers }\end{array}$ & $\begin{array}{c}\text { Teacher } \\
\text { Responsibi } \\
\text { lity }\end{array}$ \\
\hline & & $\begin{array}{l}\text { Consta } \\
\text { nt } \\
\text { meanin } \\
\mathrm{g}\end{array}$ & $\begin{array}{l}\text { It must be a } \\
\text { famous one. } \\
\text { - What do you } \\
\text { mean? } \\
\text { A well-known } \\
\text { one. } \\
\text { - Do you think it } \\
\text { was } \\
\text { carrying a large } \\
\text { or small } \\
\text { number of } \\
\text { passengers? } \\
\text { - why? } \\
\text { Because it is a } \\
\text { big ship . } \\
\text { Now students } \\
\text { begin to } \\
\text { construct } \\
\text { meaning. They } \\
\text { are reading about } \\
\text { a big } \\
\text { famous ship that } \\
\text { was } \\
\text { carrying a large } \\
\text { number } \\
\text { of passengers. }\end{array}$ & $\begin{array}{l}\text { The teacher } \\
\text { should } \\
\text { follow the } \\
\text { same steps } \\
\text { to construct } \\
\text { meaning } \\
\text { for the 1st } \\
\text { word in the } \\
\text { title "The } \\
\text { Loss" }\end{array}$ \\
\hline & $\begin{array}{l}\text { Under } \\
\text { standi } \\
\text { ng }\end{array}$ & & $\begin{array}{l}\text { Sometimes it is } \\
\text { significant } \\
\text { to talk about the } \\
\text { words } \\
\text { due to their part } \\
\text { of speech } \\
\text { and follow their } \\
\text { meaning } \\
\text { as they change to } \\
\text { another } \\
\text { part of speech. }\end{array}$ & $\begin{array}{l}\text { Main task } \\
\text { of the } \\
\text { teacher in } \\
\text { this stage is } \\
\text { to provide } \\
\text { guidance } \\
\text { through } \\
\text { controlling } \\
\text { the } \\
\text { student's } \\
\text { answers } \\
\text { and } \\
\text { leading } \\
\text { them to the } \\
\text { accurate } \\
\text { comprehens } \\
\text { ion. }\end{array}$ \\
\hline
\end{tabular}


Jurnal Sosial Humaniora Sigli (JSH)

p ISSN : 2615-3688

$e$ ISSN : 2716-0270

http://journal.unigha.ac.id/index.php/JSH

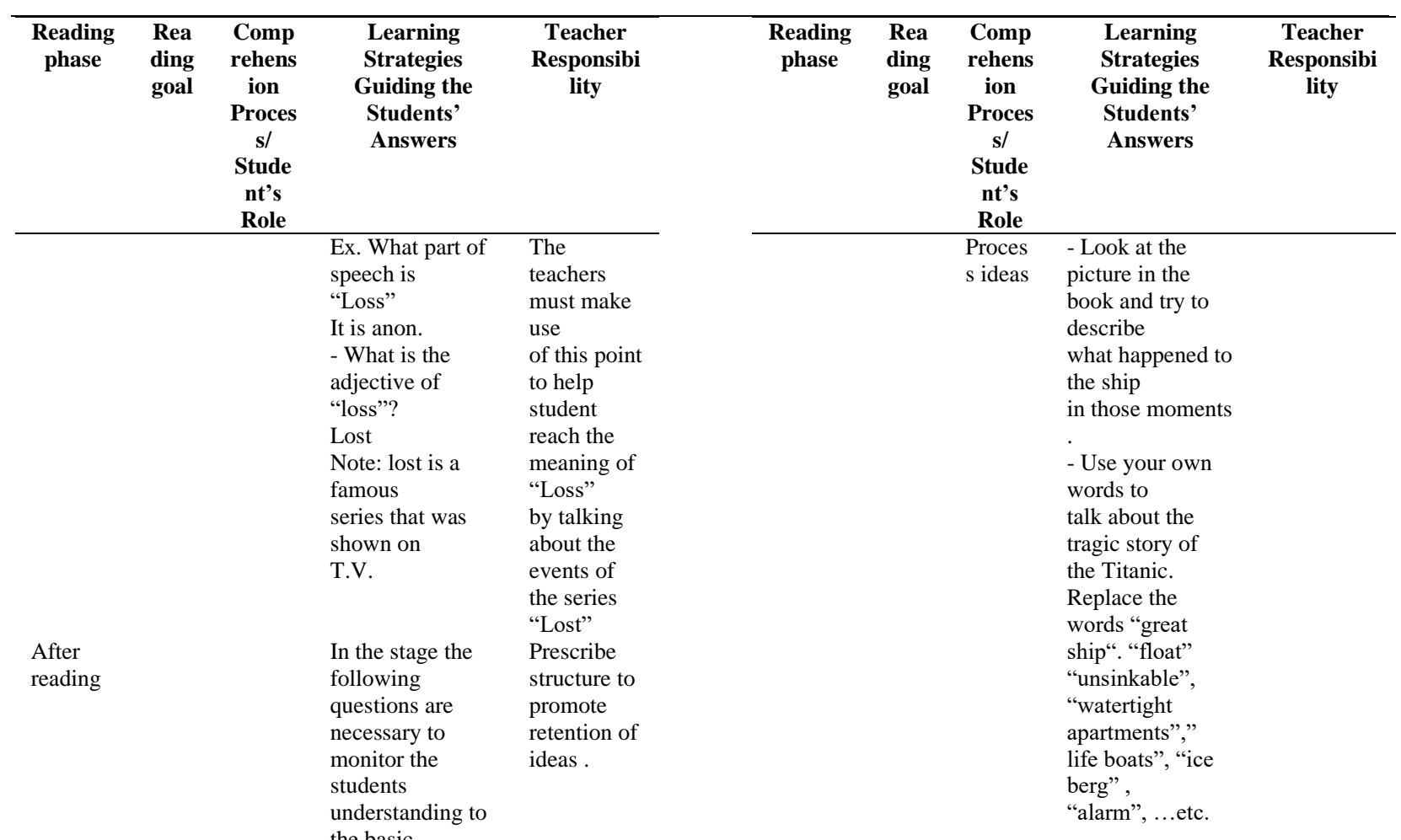

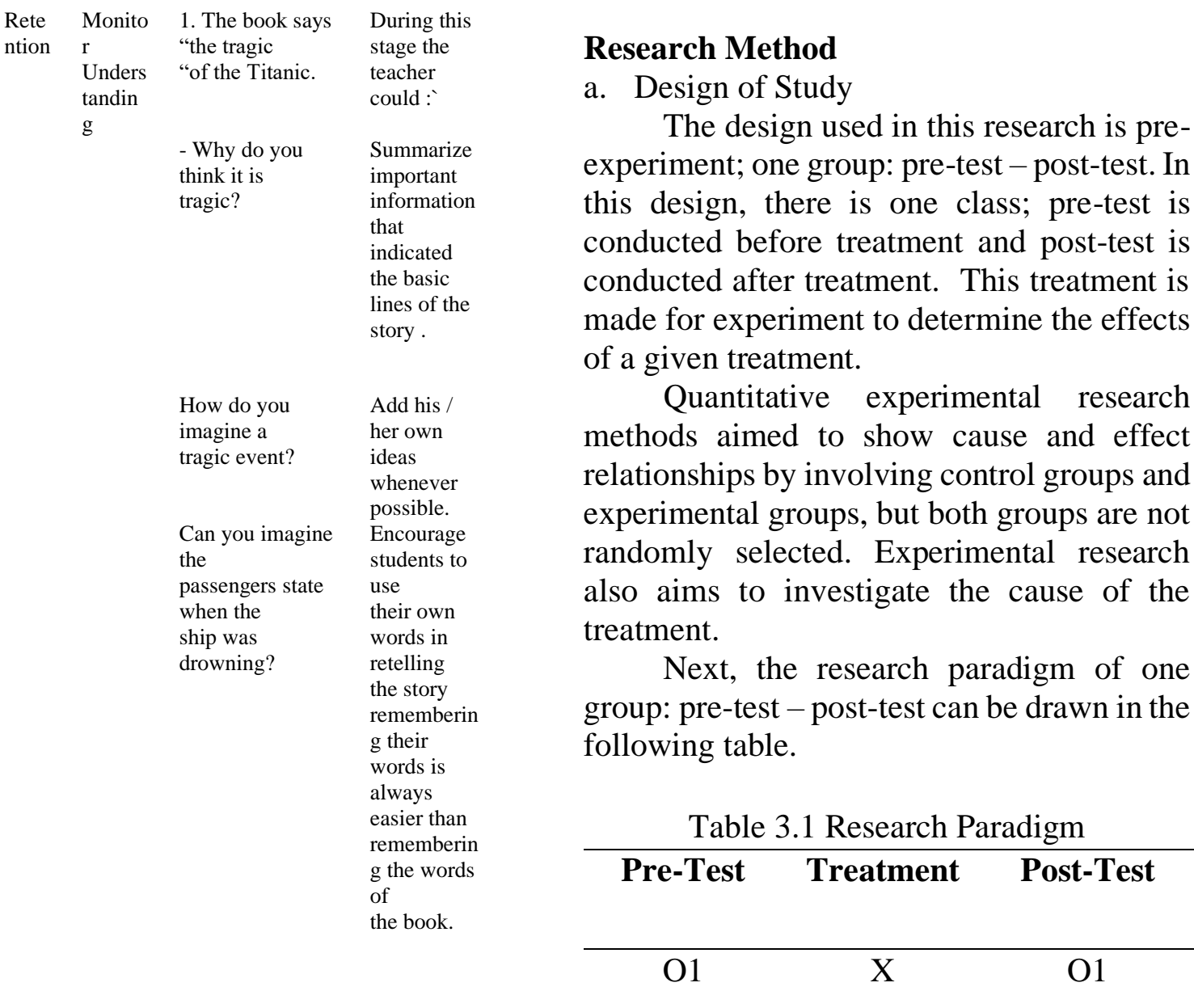


Jurnal Sosial Humaniora Sigli (JSH)

p ISSN : 2615-3688

$e$ ISSN : 2716-0270

http://journal.unigha.ac.id/index.php/JSH

In which:

O1 : Pre-test is conducted before treatment

X : Treatment

O1 : Post-test is conducted after Treatment

b. The Population and Sample

The population of this research was the eight grade students of SMP Negeri 13 Banda Aceh. The total population of this study was121 students who awere composed of five classes; VIII1, VIII2, VIII3, and VIII4. Every class consists of about 30 students.

The sample of this research was class VIII1 at second grade of SMP Negeri 13 Banda Aceh. The class consisted of 30 students. The researcher used purposive sampling technique in choosing sample. The researcher chose the students of class VIII1 because the students' ability of the class is better than the other classes. Next, purposive sampling technique is a type of nonprobability sampling that is most effective when one needs to study a certain cultural domain with knowledgeable experts within.

c. The Instrument of Study

This study uses a test and questionnare as a research instrument. The test consists of two test, namely pre-test and post-test.

1. Pre-test

Pre- test is an activity that tests the level of student's knowledge of the material to be delivered, pre-test activities are carried out before the teaching activities are given. The benefit of the pre-test is to know the initial ability of students about the lesson presented. By knowing the initial abilities of this students, the teacher will be able to determine how the lesson will be delivered later (Creswell, 2008).

2. Post-test

Post-test is the final evolution when the material taught on that day has been given which a teacher assigns to the students. The benefit of this post-test is to get an idea of the capabilities achieved after the end of the lesson delivery. The result of this post-test are compared to the pre-test result that have been done thus it will be known how far the effect or influence of teaching has been done, besides can also be known which part of the teaching material is still not understood by most students (Creswell, 2008).

d. The Data Analysis

In this research, the researcher applied qualitative and quantitative data. The quantitative data was used t-test to analyze the score of the students and the qualitative data used data display, verification, and data reduction. To know the different of the test success after using MIT strategy and to find out the differences between pre-test and posttest, the writer used the following formula suggested by Creswell (2008).

$$
\begin{aligned}
& \text { GS }=\frac{O_{2}-O_{1}}{\text { Max Score }- \text { pretest }} \\
& \text { GS } \quad=\text { Gain Score } \\
& \text { O2 } \\
& \text { O1 }
\end{aligned}
$$

Max Score $\quad=100$

Pre-test $\quad=$ Average Score of

Pre-Test

Next, the writer analyzed qualitative data from questionnaire which based on advises three simultaneous flows of activities in analyzing the data. They are data reduction, data display and conclusion drawing or verification (Miles \& Huberman, 2014).

1). Data reduction

In this study, the process of data reduction progressed concurrently as data collection proceeds. The data reduction was accomplished to simplify the data gathered. By implementing data reduction, the data will be simpler and it will make the process of data analysis easier. In this process, data reduction was performed by writing summaries, coding, making cluster, 
tabulating, and making partition. These processes proceeded until the final report is achieved. The process helped the researcher to have a clear view about this study.

\section{2). Data Display}

Data display is the second step of data analysis in a qualitative study. Data display facilities the researcher in the process of data analysis, the ideas and interpretations of the data will be clearer. In this study, the field notes would be display in an extended text to describe the implementation of extensive reading activity in reading class, while the result of observation sheet would be display in table. The result of the interview would be display in extended text.

3). Conclusion Drawing and Verification

Conclusion drawing and verification is the third step of the data analysis in qualitative study. Conclusion drawing interpretations were made on the data analyzed after doing data reduction and data display processes to attained data from classroom observation (diary notes and observation sheet) and interview. Subsequently, some conclusion were drawn which were related to the researcher question.

3. The Result of the Research and

Discussion

After getting the data, the writer calculates the average score of pre-test and posttest that was gotten by the students and to find out the average score, the researcher calculates the data by using SPSS Version 22. The result of the calculation is shown in table 4.3 as follows:

Table 4.3 The Students' Average Score of Pre-Test and Post-Test

\begin{tabular}{|c|c|c|c|c|c|}
\hline & & $\mathrm{N}$ & Mean & $\begin{array}{c}\text { Std. } \\
\text { Deviatio } \\
\text { n }\end{array}$ & $\begin{array}{c}\text { Std. Error } \\
\text { Mean }\end{array}$ \\
\hline $\mathrm{Sc}$ & Pre- & 3 & 58.00 & 6.644 & 1.213 \\
\hline ore & Test & 0 & & & \\
\hline
\end{tabular}

\begin{tabular}{ccccc} 
Post & 3 & 68.00 & 10.306 & 1.882 \\
- & 0 & & & \\
Test & & & & \\
\hline
\end{tabular}

Table 4.3 shows that the average score of pre-test is 58.00 in mastering reading skill meanwhile the average score of post-test is 68.00 in mastering reading skill. The average score of pre-test is gotten before the students are given treatment. Meanwhile the average score of post-test is gotten after the students are given treatment. Furthermore, the students' average score of post-test is higher than the students' average score of pre-test. Thus, the students' ability in mastering reading skill after they are taught reading skill by using MIT (Mediated Instruction of Text) Strategy is better than before they are taught reading skill by using English as medium in instruction.

Next, the writer calculates the data of pre-test and post-test to find out if the usage of MIT strategy in teaching sreading skill is better than the common way or the usage of MIT strategy in teaching students' reading skill is not better than the common way.

The result of the calculation is presented in the following formula of difference between pre-test and post-test.

$$
\begin{aligned}
& G S=\frac{\mathrm{O}_{2}-\mathrm{O}_{1}}{\text { MaxScore }- \text { pretest }} \\
& G S=\frac{68-58}{100-58}
\end{aligned}
$$

$$
G S=\frac{10}{42}=0.24
$$

Based on the statistical analysis, it is found that the Gain Score (GS) score is 0.24. It means there is a difference between the students' ability in mastering reading skill before and after they are taught by using MIT 
Jurnal Sosial Humaniora Sigli (JSH)

p ISSN : 2615-3688

$e$ ISSN : 2716-0270

http://journal.unigha.ac.id/index.php/JSH

strategy and the difference is 0.24 points or $24 \%$. Therefore, the students' ability in mastering reading skill increases 0.24 points or $24 \%$ after they are taught by using MIT strategy.

Next, it can be concluded that the usage of MIT strategy in teaching reading skill is better than the common way. In the other words, it can be stated that the usage of MIT strategy in teaching students' reading skill is better than the common way.

In addition, the frequency score of the pre-test is presented in the following table.

Table 4.5 Frequency Scores of Pre-Test

\begin{tabular}{rrrrrr}
\hline & & $\begin{array}{c}\text { Freque } \\
\text { ncy }\end{array}$ & Percent & \multicolumn{1}{c}{ Palid } & \multicolumn{1}{c}{$\begin{array}{c}\text { Pumulative } \\
\text { Percent }\end{array}$} \\
\hline Valid & 50 & 7 & 23.3 & 23.3 & 23.3 \\
& 55 & 9 & 30.0 & 30.0 & 53.3 \\
& 60 & 7 & 23.3 & 23.3 & 76.7 \\
& 65 & 3 & 10.0 & 10.0 & 86.7 \\
& 70 & 4 & 13.3 & 13.3 & 100.0 \\
\hline & Total & 30 & 100.0 & 100.0 & Total \\
\end{tabular}

Table 4.5 shows the that 7 student $(23.3 \%)$ gets score 50,9 students $(30 \%)$ gets score 55,7 students $(23.3 \%)$ get score 60,3 students $(10 \%)$ get score 65 , and 4 students $(13.3 \%)$ get score 70 .

Base on the description, the writer concludes that the most students get score 55 in mastering reading skill. Next, the writer presents the frequency score of pre-test in the following histogram.

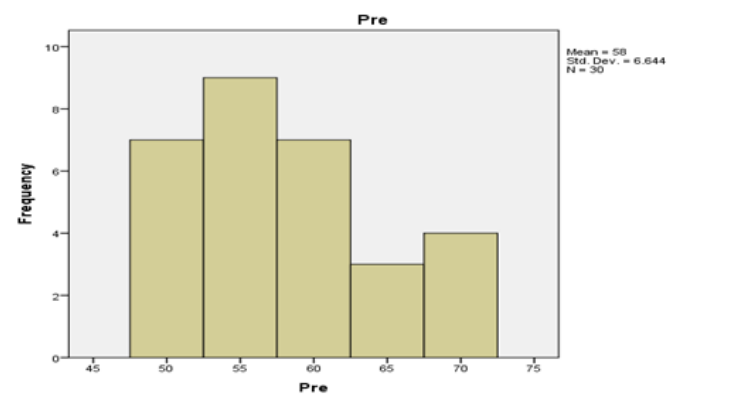

Figure 1. Histogram of Pre-Test

Based on the histogram of pre-test, it can be stated that 7 student $(23.3 \%)$ gets score 50,9 student $(30 \%)$ gets score 55,7 students $(23.3 \%)$ get score 60,3 students (10\%) get score 65, and 4 students $(13.3 \%)$ get score 70 .

Base on the description, the writer concludes that the most students of the both groups get score 55 in mastering reading skill.

Next, the frequency score of the pretest can be presented in the following table.

Table 4.6 Frequency Scores of Post-Test

\begin{tabular}{cccrrr}
\hline & & $\begin{array}{c}\text { Frequ } \\
\text { ency }\end{array}$ & $\begin{array}{c}\text { Perce } \\
\text { nt }\end{array}$ & $\begin{array}{c}\text { Valid } \\
\text { Perce } \\
\text { nt }\end{array}$ & $\begin{array}{c}\text { Cumu } \\
\text { lative } \\
\text { Perce } \\
\text { nt }\end{array}$ \\
\hline Valid & 50 & 2 & 6.7 & 6.7 & 6.7 \\
& 55 & 4 & 13.3 & 13.3 & 20.0 \\
& 60 & 3 & 10.0 & 10.0 & 30.0 \\
& 65 & 5 & 16.7 & 16.7 & 46.7 \\
& 70 & 6 & 20.0 & 20.0 & 66.7 \\
& 75 & 4 & 13.3 & 13.3 & 80.0 \\
& 80 & 3 & 10.0 & 10.0 & 90.0 \\
& 85 & 3 & 10.0 & 10.0 & 100.0 \\
\hline & Total & 30 & 100.0 & 100.0 & \\
\hline
\end{tabular}

Table 4.6 shows the that 2 student $(6.7 \%)$ gets score 50,4 students $(13.3 \%)$ gets score 55, 3 students (10\%) get score 60, 5 students $(16.7 \%)$ get score 65,6 students (20\%) get score 70.4 students $(13.3 \%)$ get score 75,3 students (10\%) get score 80 , and 3 students (10\%) get score 85 .

Base on the description, the writer concludes that the most students get score 70 in mastering reading skill. In addition, the writer presents the frequency score of posttest in the following histogram.

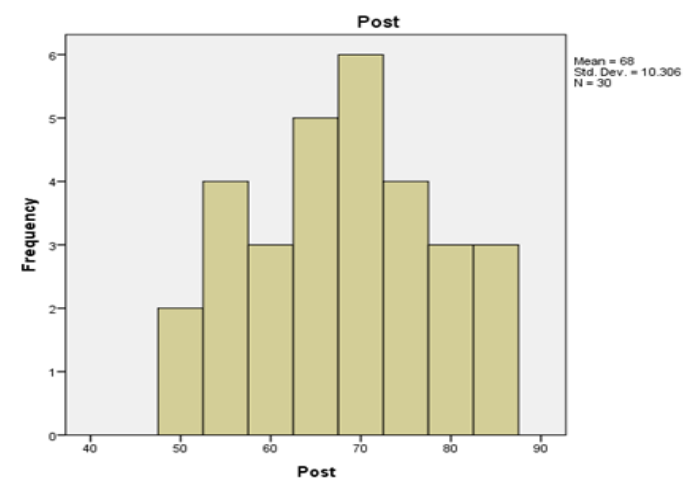




\section{Figure 2. Histogram of Post -Test}

Based on the histogram, it can described that 2 student $(6.7 \%)$ gets score 50 , 4 students $(13.3 \%)$ gets score 55,3 students (10\%) get score 60,5 students $(16.7 \%)$ get score 65, 6 students (20\%) get score 70.4 students $(13.3 \%)$ get score 75,3 students (10\%) get score 80 , and 3 students (10\%) get score 85 .

Base on the description, the writer concludes that the most students get score 70 in mastering reading skill.

\section{The Data Findings of Questionnaire}

The data collected on the students' opinion of SMP Negeri 13 Banda Aceh in learning reading skill by using Mediated Instruction of Text (MIT) Strategy. Next, based on the data findings of questionnaire, the researcher found that (1) the most students (40\%) agree very much that the use of MIT strategy can increase their vocabulary, (2) the most students $(46.7 \%)$ who disagree that the use of English and Indonesian together in an instruction can spoil language elements, (3) that the most students $(33.3 \%)$ agree that usage of MIT Strategy can increase the students' motivation in reading books that are written in English, (4) the most students (33.3\%) disagree very much that usage of MIT strategy can repress local language, and (5) the most students (40\%) agree very much that the usage of MIT trategy make the students more diligent to find new vocabularies in dictionary.

\section{Discussion}

Since the design used one sample; pretest and post-test thus pre-test must be given to the students before conducting experiment. Next, the result of pre-test shows that the students' average score is 58. Furthermore, the students' average score of pre-test is 68 after they are taught by using Mediated Instruction of Text (MIT) Strategy in reading skill instruction. Thus, the students' ability in mastering reading skill before treatment is 58 and it is not very satisfying. It happens because the students are not motivated to learn reading skill. One of factors that make students unmotivated in learning reading skill because the strategy that is used by a teacher is not appropriated for students. Thus, the researcher tries to improve the students' ability in mastering reading skill by conducting a teaching and learning process of reading skill through MIT strategy.

After the researcher taught reading skill to the students using MIT strategy, the students' ability in mastering reading skill increases and the increase is about 10 points. The students' ability in mastering reading skill increases because they enjoy following teaching and learning process. Next, the use of MIT strategy in teaching and learning process makes the students happy and motivated to follow the teaching and learning process.

Then, after the researcher gave pre-test and analyzed it, the writer conducted teaching and learning process (tretament) of reading skill by using MIT strategy. Next, after the researcher conducts teaching and learning process of reading skill, the writer conducts post-test. The result of the post-test in which the average score of post-test (68) are greater than the average score of pre-test (58). Thus, the use of MIT strategy in teaching reading skill to the students of SMP Negeri 13 Banda Aceh is effective to improve the students in mastering reading skill.

Next, the students' motivation increases when they are taught reading skill by using MIT strategy. Therefore, their ability in mastering reading skill is better after they are taught reading skill through MIT strategy. 
In addition, based on the data findings of questionnaire, the researcher found that (1) the most students agree very much that the use of English language as medium of instruction can increase your vocabulary, (2) the most students who disagree that the use of English and Indonesian together in an instruction can spoil language elements, (3) that the most students agree that usage of English as the language of instruction can increase the students' motivation in reading books that are written in English, (4) the most students disagree very much that usage of English as the language of instruction can repress local language, and (5) the most students agree very much that the usage of English as the language of instruction make the students more diligent to find new vocabularies in dictionary.

Finally, there is a novelty of this research and the novelty is that the use of MIT strategy in teaching and learning process is a new strategy which is effective to be used in teaching reading skill at SMP Negeri 13 Banda Aceh. Besides, the design used in this study is experimental research. Meanwhile, the previous researchers who conducted a research about using MIT strategy in teaching reading skill used classroom action design meanwhile the writer used pre-experimental research design.

\section{Conclusions}

Based on the result of study and its analysis, some conclusions can be drawn as follows:

1. The students' ability of SMP Negeri 13 Banda Aceh are good category because their average score is 68 after they are taught by using English as the language of instruction. Their ability increases 10 point after they are taught by using MIT strategy. Thus, teaching reading skill to the students of SMP Negeri 13 Banda by using MIT strategy is successful because the students' ability in mastering reading

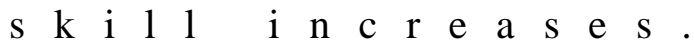

2. The usage of MIT strategy in teaching streading skill is better than the common way. It can be proved that the result of this research shows the difference between pre-test and post-test is 0.24 Thus, the students' ability in mastering reading skill increases $24 \%$ after they are taught through MIT strategy .

3. The students' motivation of SMP Negeri 13 Banda increases when they are taught reading skill by using MIT strategy.

\section{References}

Adler, C.R. (2004). Seven Strategies to Teach Students Text Comprehension. Available on: http:// readingtokids.org/Reading Clubs/Tip Reading Comprehension. php

Alyousef, H.S. (2005). Teaching reading comprehension to ESL/EFL Learners. Journal: The Reading Matrix Vol.5, No.2, September 2005. www.readingmatrix.com/articles

Birdyshaw, D. (2001). Improving the Reading Comprehension of America's Children10 Research-Based Principles. Available on: http://www.ciera. org/library/inst resrc/compprinciples/

Creswell, J. W. (2008). Educational Research: Planning, Conducting, and Evaluating Quantitative and Qualitative Research. New Jersey: Pearson Education.

Elliot, S. (2008). How to be a more successful reading. Boston: Boston and Heinle Publisher.

Mayasari. (2011). The Use of MIT (Mediated Instruction of Text) Strategy in 
Jurnal Sosial Humaniora Sigli (JSH)

p ISSN : 2615-3688

$e$ ISSN : 2716-0270

http://journal.unigha.ac.id/index.php/JSH

Teaching Reading Comprehension. Thesis: Unpublished. Surabaya: UNESA.

Maysa' A. (2011). The Mediated Instruction of Text ( MIT) Strategy for Reading Comprehension. Journal of College of Education for Women 2011, Volume 22, Issue 4, Pages 906

917

Mikulecky, B.S. \& Linda, J. (2004). More Reading Power. Reading for Pleasure, Comprehension Skills, Thinking Skills, Reading Faster. 2nd Edition. New York: Longman.

Miles, M.,B. \& Huberman, A., M. (2014). Qualitative Data Analysis. (terjemahan). Jakarta : UI Press. Miles, M.B, Huberman ,A.M, dan Saldana,J. 2014.

Muhadjir. (2012). Teaching Reading Comprehension Through (Mediated Instruction of Text) Strategy. Thesis: Unpublished. Malang: UM.
Neal, P., N. \& Langer, T., I. (1992). The Mediated Instruction of a Text. Englewood: Prentice Hall.

Nunan, D. (2003). Practical English Language Teaching. New York: McGraw.

Rohmawati, D. (2015). The Use of MIT (Mediated Instruction of Text) Strategy and Printed Material to Improve Reading Skill to the Eight Grade Students of SMP N 2 Bandung Satu Atap Semarang in Academic Year of 2015/2016. Other thesis, IAIN http://erepository.perpus.iainsalatiga.a c.id/.

Sariakin. (2016). Model based development of English language learning characters in improving students achievement. Peuradeun International Journal. Volume. 4, No.2. Page: 173-182. Banda Aceh: State Islamic University of $\mathrm{Ar}$ Raniry.website.www.scadindepemdent .org 